\title{
Development and Performance Evaluation of a Multi-Heat Source Plantain Roaster
}

\author{
M. O. Jimoh*, O. A. B. Ogunmoyela, O. N. Ogabi \\ Department of Chemical and Food Sciences, Bells University of Technology, Ota, Nigeria.
}

ABSTRACT: The increasing demand for roasted plantain has brought about recent interest to upgrade the local method of roasting to be more user-friendly, hygienic and versatile. The objective of this work was to design, fabricate and evaluate the performance of a low cost and affordable multi-heat source plantain roaster and to determine the effects of different heat sources (charcoal, gas and electricity) on the proximate and micronutrients composition of the roasted plantain. Heat supplied to each compartment and medium of transfer was determined. The roasted products from different heat sources were evaluated for moisture, crude protein, ash, crude fat, crude fibre and total carbohydrate contents of the samples. Potassium, magnesium and vitamin B6 were also determined. The proximate and micronutrient composition analyses were carried out. The results show that the average capacity and efficiency of the machine is $3.74 \mathrm{~kg} / \mathrm{h}$ and $96.32 \%$ respectively. Moisture content of the fresh plantain is $58.27 \%$ while that of roasted plantain using gas, electricity and charcoal are $46.26 \%, 45.94 \%$ and $39.59 \%$ respectively. Ash content of fresh plantain is $5.89 \%$ while that of roasted plantain using gas, electricity and charcoal are $7.45 \%, 8.30 \%$ and $7.00 \%$ respectively. Crude fibre content of fresh plantain is $2.83 \%$ while that of roasted plantain using gas, electricity and charcoal are $3.27 \%, 3.41 \%$ and $3.43 \%$ respectively. Carbohydrate content of fresh plantain is $23.80 \%$ while that of roasted plantain using gas, electricity and charcoal are $33.41 \%, 32.35 \%$ and $43.02 \%$ respectively.

KEYWORDS: Machine design, plantain, moisture content, micronutrient analysis, heat source, roasting

\section{INTRODUCTION}

Plantain is a starchy, less sweet variety of banana which cannot be eaten raw (unlike banana) because it contains indigestible tannins (Idoko and Nwajiaku, 2013; Akomolafe and Aborisade, 2007). About $80 \%$ of plantains grown throughout the world are of the banana variety (Castello, 2006). One large plantain is about $26 \mathrm{~cm}$ in length and $6.5 \mathrm{~cm}$ width, having $602 \mathrm{mg}$ of potassium and 140 calories (Izunfuo and Omuaru, 2006). Plantain is a staple food in the developing world and it contains about $52.9 \%$ moisture, $0.8 \%$ protein, $0.1 \%$ fat, $25.5 \%$ carbohydrate, $0.3 \%$ fibre and $0.63 \%$ ash (Marisa, 2006). It was considered an important food to boost the health of malnourished children and recommended by medical doctors for those whose potassium level is low (Adegboyega, 2006). Plantain is rich in vitamins A, C and B group as well as minerals such as calcium and iron (Ayodele and Erema, 2011). Investigations have shown that cooking methods or processing techniques of foods often lead to losses of vitamins such as water soluble vitamin and the fat soluble vitamins (Yang and Gadi, 2008).

Roasting is a process by which agricultural products are exposed to dry heat in an oven or over a fire for the purpose of removing moisture and cooking to a state that the products are suitable for consumption (Makanjuola et al., 2013). Smoked unpeeled-plantain is common among rural dweller using uncontrollable heat source. This process prevents toxic hydrocarbon and microbial contamination (Idoko and Nwajiaku, 2013). However, it has been revealed that plantain peel is a source of dietary fibre and pectins (FAO, 2010). Ripe plantain fruit when eaten neutralizes acidity and reduces irritation by coating the stomach lining (Izunfuo and Omuaru, 2006). A number of research investigations have also revealed that unripe-plantain when consumed could be a potential diet for the diabetics (Eleazu et al., 2010; Kusano et al., 2005; Kusano et al., 2001). As the plantain gradually ripens, it becomes sweeter and its colour changes from green to yellow (Adewumi, 2007).

During roasting, there is transmission of energy from the heat source to the plantain as a result of temperature gradient, thus altering the eating quality of the food to cause some desirable physical and chemical changes and to enhance food flavor (Oke, 2013). This desirable quality developed in the product is as a result of reduction of the water activity at the surface of the food (Oke and Ogundare, 2012). Use of high temperature in roasting facilitates complex changes to the components of the food at the surface and retention of moisture in the interior of the food product (Oke and Ogundare, 2012). 
The traditional method of roasting plantain is done by placing the charcoal inside a tray with a metal grill is placed on top of the tray mainly to separate the plantain to be roasted and charcoal (Ilori et al., 2014).

Many researchers had worked on roasting machine (Toledo, 2000; Ilori et al., 2014; and Awopetu and Aderibigbe, 2017). Emphases were on convective heat transfer. Apparently, the transfer of heat is by conduction and convection from the surface to the interior part of the food. However, when the surface temperature is high, or when the surface loses heat by natural convection, then the heat transfer due to radiation is of a similar magnitude to that lost by convection (Ogunmoyela et al., 2016). In view of this challenge, this research is focused on development of a multiheat source plantain roaster and to determine the effect of heat transfer using different sources on the proximate and micronutrient composition of the roasted plantain.

\section{MATERIALS AND METHODS}

\section{A. Material Selection and Design Considerations}

Unripe plantain was harvested from Yola's farm, Ikorodu, Lagos, Nigeria. The fingers were removed using a sterilized knife. The plantains were then washed to removed dirt and dust that could contaminate the product before peeling. The peeled plantains were roasted using the developed roaster. In the design of a multi-heat source plantain roaster, various factors were considered in the selection of material including availability of the materials, durability of materials, and suitability of the materials for the desired performance and the cost of the materials.

\section{B. Machine Description}

The plantain roaster was designed to have three alternative energy sources, namely electricity, gas and standard charcoal. The components include cylindrical stainless steel basket, turning handle, external components such as switch, thermostat, electric heater, fan, gas burner, gas control, gas pipe, hinges, and charcoal compartment. The frame was divided into three rectangular but equal sections. This was to facilitate a standing support to the roasting net. The roasting net is cylindrical in shape, made of a stainless steel and constructed in such a way that it can fit inside the fabricated frame. It was constructed to move freely unhindered when turning the handle.

This allows for free movement of heat by conduction, convection and radiation. The top is rectangular in shape, made of mild steel and attached to a hinge for an easy open and close movement. The gas burner and electric heater were welded to the frame. The electric heater has a power of $1800 \mathrm{~W}$ with a sensor wired on it to detect changes in temperature. Thus, when the heat gets to the set temperature, it trips off automatically and then when it is below the set temperature, the temperature begins to rise again and vice versa. The charcoal compartment was constructed on a load basis of $2 \mathrm{~kg}$ of charcoal for heating the plantain while the gas cylinder is connected to the burner with long hose. Figure 1 shows the exploded view of the machine.

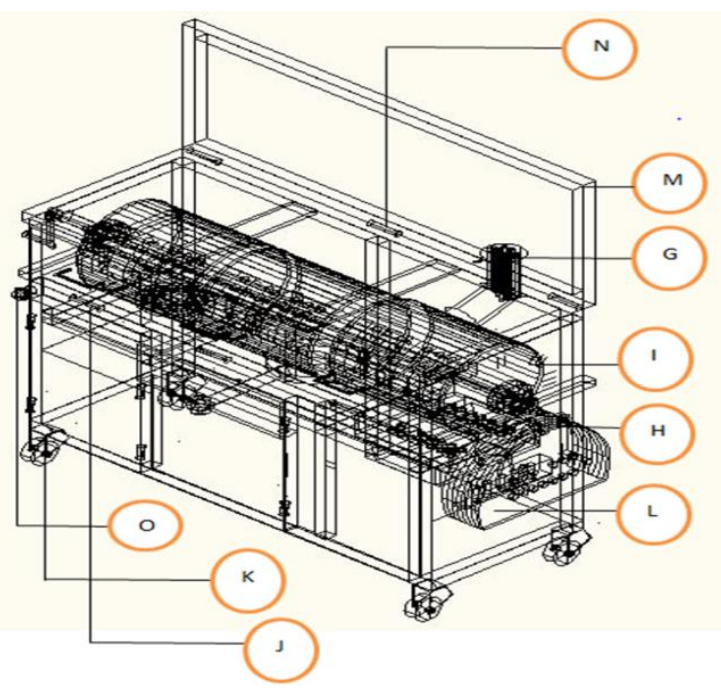

Figure 1: The Exploded view of the machine.

G- Chimney, $H$ - the turning handle, I- Roasting basket, J-Door handle, $K$ - the tyre, L- Fan compartment, $M$ - Lid cover, $N$ - Hinges, $O$ - Control switch, $T$ - the frame

\section{Design Calculation and Performance Evaluation}

The major source of heat transfer in this system is by conduction through the roasting net as defined by Fourier's law of heat conduction. Certainly, there will be heat loss to the atmosphere by radiation. The optimum temperature for both the electricity and gas source was $200{ }^{\circ} \mathrm{C}$ while that of charcoal was $190{ }^{\circ} \mathrm{C}$, the temperature at which the plantain attained acceptable colour at shortest time. The ambient temperature was $30^{\circ} \mathrm{C}$.

$$
Q=-K A \frac{d t}{d x}
$$

Where $\mathrm{Q}$ is heat transferred by conduction, $K$ is thermal conductivity of the stainless steel roasting net and minus sign indicated shows that it obeys second law of thermodynamics, $A$ is cross sectional area of the roasting net through which heat flow to the plantain, $\partial T / \partial x$ is temperature gradient in the direction of heat flow.

$$
\begin{aligned}
& Q=Q_{\text {conv }}+Q_{\text {cond }}+Q_{\text {rad }} \\
& Q=\left[h A\left(t_{s}-t_{f}\right)+\left(-K_{p} A \frac{d t}{d x}\right)\right]+Q_{\text {rad }}
\end{aligned}
$$

Where $\mathrm{Q}_{\text {conv }}, \mathrm{Q}_{\text {cond }}$ and $\mathrm{Q}_{\text {rad }}$ are heat transfer by convection, conduction and radiation respectively (Ogunmoyela et al., 
2016), $\mathrm{h}$ is the convective heat transfer coefficient $31.77 \mathrm{~W} / \mathrm{m}^{2}$ ${ }^{\circ} \mathrm{C}$ (Ezekiel et al., 2012), $\mathrm{K}_{\mathrm{p}}$ is the thermal conductivity of the plantain $0.594 \mathrm{~W} / \mathrm{m} \quad{ }^{\circ} \mathrm{C}$, (Fellows 2000; Jimoh and Ogunmoyela, 2017), $t_{f}$ average room temperature before heating in ${ }^{\circ} \mathrm{C}, \mathrm{t}_{\mathrm{s}}$ surface temperature of the plantain in ${ }^{\circ} \mathrm{C}$.

Mass $\left(\mathrm{m}_{1}\right)$ of different unripe plantain was weighed and determined to be $130 \mathrm{~g}$ on average. For a maximum load of 7 fingers of unripe plantain per roasting grid, the mass averaged $0.91 \mathrm{~kg}$. The selection of unripe plantain for this study was in line with recommendation of World Health Organization to diabetes patients, arising from current global health challenges and the exponential growth of chronic diseases (WHO, 2004).

The plantain roaster was heated to $200{ }^{\circ} \mathrm{C}$ while empty when using gas and electric sources and to $190{ }^{\circ} \mathrm{C}$ when using charcoal as the heat source. The time taken to achieve this temperature was noted. Efficiency of temperature regulation control and the electric switch was observed through regular tripping off and switching back on the heating element. The gas control was tested for the level of pressure decrease and increase in the rate at which the gas flowed. The gas was tested based on the colour of the flame produced. The gas burner was constructed inside the enclosed compartment in form of a gas oven. The charcoal was tested by the level of heat it produced when empty. The efficiency of the charcoal when it produces energy was tested compared to the volume of charcoal in the compartment.

The machine capacity is expressed in eqn (4) while the machine efficiency is calculated using eqn (5).

$$
M C(k g / h)=\frac{W}{T}
$$

where $W$ is the weight of plantain fingers $(\mathrm{kg})$ and $T$ is the time taken to roast plantain (h).

Efficiency of the machine $(\%)=\frac{E_{1}}{E_{2}} \times 100$

where $E_{1}$ is the energy output and $E_{2}$ is the energy input.

The power required to turn empty basket and the force required to turn the weight of the plantain during roasting are illustrated in eqns (6) and (7) respectively.

$$
\begin{aligned}
& P^{1}=m_{2} g L \\
& F=m_{1} g
\end{aligned}
$$

where $m_{2}$ is the mass of the rod, $g$ is the centre of gravity and $L$ is the length of the roasting basket.

In this study, $P_{I}$ is computed as $100.33 \mathrm{~W}$ while $P$, the power required to turn the basket with plantain is computed as 102.77 W using eqn (8).

$$
P=m_{2} g L+F
$$

Luckily, this falls within the sustainable human potential power 70 - $500 \mathrm{~W}$ (Ogabi, 2018).

\section{Determination of Nutritional Composition of Sample}

The proximate composition of the samples was carried out by the methods described by AOAC, (2005). Nutritional compositions determined were crude protein content, total ash, crude fat, total carbohydrate content and moisture content of the samples.

\section{E. Micronutrient Analysis}

The samples were digested by wet-digestion method using a combination of chloric acid, nitric acid and sulfuric acid (AOAC, 2005). Magnesium concentration was determined by atomic absorption spectrophotometry (Pye Unicam SP9 atomic absorption spectrophotometer, Cambridge, UK and method described by the AOAC). Potassium was determined by flame photometry. Vitamin B-6 was determined using extraction media $(50 \mathrm{ml} 0.1 \mathrm{M} \mathrm{Hcl})$ on milled dried unripe sample. The sample was mixed to a homogenous dispersion by magnetic stirrer as described by AOAC (2000).

\section{F. Statistical Analysis}

The data obtained were made in triplicates and analysed using one way Analysis of Variance (ANOVA) of Statistical Package for Social Sciences (SPSS version 17.0). Significant means were separated using the New Duncan's Multiple Range Test (NDMRT) at 95\% confidence interval.

\section{G. Sensory Evaluation}

Consumer assessment of overall acceptability of the roasted plantain was done, according to (Sanni et al., 2016). Twenty male and twenty female staff of Bells University of Technology, Ota, Nigeria were chosen. These are regular consumers of roasted plantain and were randomly selected for the evaluation. Each sample of roasted plantain using gas, electricity and charcoal heat sources was placed in separate identical tight polythene bags. The bags were coded as samples 1,2 and 3 respectively and were placed on a clean table.

A questionnaire was designed and distributed among the forty respondents to score five attributes namely colour, flavour, hardness, moisture release and chewiness on a Hedonic scale of 5 points: $1=$ poor; $2=$ fair; $3=$ satisfactory; $4=$ good; $5=$ excellent. Each of the three roasted plantain samples was presented at different times to each of the forty respondents to avoid any bias in judgement. The responses were collated to compare the consumer preferences of the roasted plantain produced using different heat sources. 


\section{RESULTS AND DISCUSSION}

\section{A. Machine Performance Evaluation}

The plantain roaster took 20 minutes for electricity and gas and 25 minutes for charcoal heat source to reach the desired temperatures of $200{ }^{\circ} \mathrm{C}$ and $190{ }^{\circ} \mathrm{C}$ respectively. The machine was loaded with 7 fingers of plantain per roasting cycle per compartment, dropped in chamber temperatures by $20{ }^{\circ} \mathrm{C}, 15$ ${ }^{\circ} \mathrm{C}$ and $15^{\circ} \mathrm{C}$ respectively for the electricity, gas and charcoal sources after loading. This may be attributed to the product bringing the temperature to equilibrium with the surrounding air since the initial temperature of plantain was lower than that of heated air in the roasting chamber (Ogunmoyela et al., 2016). The snapshot of the machine is shown in Figure 2. The vapour being released from the plantain surface escaped as the heat continued.

Thus, the colour of the plantain gradually changed to brown as shown in Figure 3a, b and c for gas, electricity and charcoal heat sources respectively. Heat conducted by the roasting net and the plantain during the production of the roasted product (boli) was transferred by convection to the interior of the food and to the surrounding air by radiation.

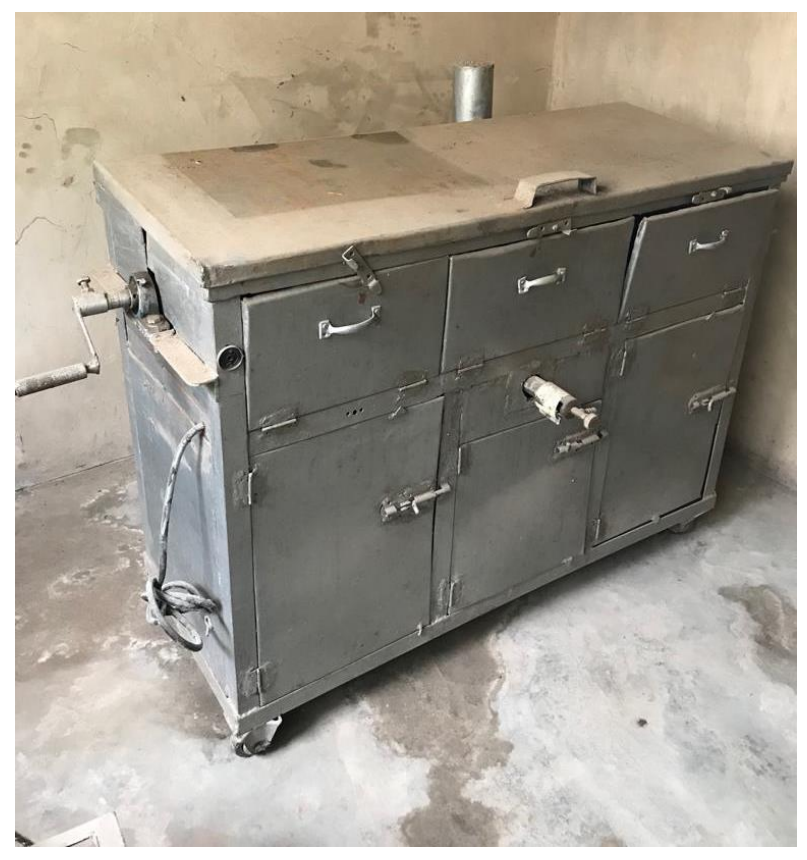

Figure 2: Snapshot of plantain roaster.

The results of heat transfer rate as shown in Table 1 revealed that total heats supplied to the roasting compartment was $846.28 \mathrm{~W}, 846.28 \mathrm{~W}$ and 793.60 W for gas, electricity and charcoal heat source respectively. These results are at variance with the findings of Ezekiel et al., (2012) who reported 1583 $\mathrm{W}$ as energy needed to roast plantain. This could be as a result of ripening of the plantain because during ripening, moisture level increases and consequently, more energy would be
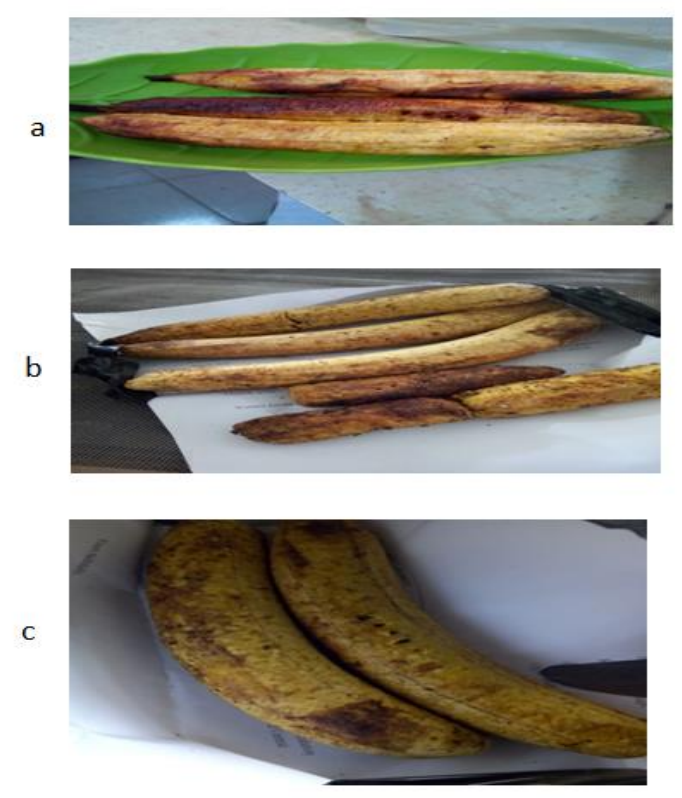

Figure 3: Roasted plantain using gas heat source (a), electric heat source (b) and charcoal heat source (c).

needed to convert the additional moisture to steam and drive it to the surface (Adegboyega, 2006). The conductive heat required to roast the plantain was $538.02 \mathrm{~W}, 538.02 \mathrm{~W}$ and $506.37 \mathrm{~W}$ for gas, electricity and charcoal heat source respectively. The convective heat transfer was $277.19 \mathrm{~W}$, $277.19 \mathrm{~W}$ and $258.00 \mathrm{~W}$ for gas, electricity and charcoal heat source respectively. Heat loss by radiation was $31.07 \mathrm{~W}, 31.07$ $\mathrm{W}$ and $29.23 \mathrm{~W}$ for gas, electricity and charcoal heat source respectively. The average capacity of the machine was determine to be $3.74 \mathrm{~kg} / \mathrm{h}$ while the machine efficiency was found to be $96.32 \%$ when using any of the three compartments.

Table 1: Heat transfer rate for the roasting machine.

\begin{tabular}{lcccc}
\hline $\begin{array}{l}\text { Roaster } \\
\text { Compartment }\end{array}$ & $\begin{array}{c}\text { Heat } \\
\text { Supplied } \\
\text { (W) }\end{array}$ & $\begin{array}{c}\text { Heat of } \\
\text { Conduction } \\
(\mathbf{W})\end{array}$ & $\begin{array}{c}\text { Heat of } \\
\text { Convection } \\
(\mathbf{W})\end{array}$ & $\begin{array}{c}\text { Heat of } \\
\text { Radiation } \\
(\mathbf{W})\end{array}$ \\
\hline Gas & 846.28 & 538.02 & 277.19 & 31.07 \\
Electricity & 846.28 & 538.02 & 277.19 & 31.07 \\
Charcoal & 793.60 & 506.37 & 258.00 & 29.23 \\
\hline
\end{tabular}

\section{B. Effect of Roasting Method on Proximate Composition}

The moisture, ash, crude fibre, carbohydrate, fat and protein contents values of fresh plantain were found to be $58.27 \%, 5.89 \%, 2.83 \%, 2380 \%, 2.16 \%$ and $6.90 \%$ respectively as presented in Table 2 . This result was not compatible with the one reported by INIBAP (2003) who reported $52.9 \%, 0.63 \%, 0.3 \%, 25.5 \%, 0.1 \%$ and $0.8 \%$ for moisture, ash, crude fibre, carbohydrate, fat and protein respectively. This could be as a result of difference in variety and level of ripening (Ezekiel et al., 2012). The proximate composition of roasted plantain as shown in Table 2 revealed 
that moisture content of the plantain in gas, electricity and charcoal heat sources was $46.26 \%, 45.94 \%$ and $39.59 \%$ respectively. These moisture figures were found to be significantly low at 5\% level of significance than that of fresh plantain. This could be as a result of spontaneous conversion of moisture to vapour during heating (Jimoh and Ogunmoyela, 2017). However, the mean moisture contents of the products from gas and electric heat sources were not significantly different.

The fat content of plantain using gas, electricity and charcoal heat sources was $4.52 \%, 4.68 \%$ and $4.64 \%$ respectively. The fat contents showed statistical significance at the $5 \%$ level of probability, $(\mathrm{p}<0.05)$, the means of products from the gas and charcoal heat sources were also not significantly different. The proximate analysis of roasted plantain revealed that protein content in gas, electricity and charcoal heat sources was determined to be $8.11 \%, 8.35 \%$ and $5.38 \%$ respectively. The protein content using charcoal heat source was significantly low at $5 \%$ level of probability. This could be as a result of prolonging residence time peculiar to charcoal roasting (Ilori et al., 2014). However, the means of protein for products roasted using gas and electric heat sources were not significantly different.

The crude fibre content using gas, electricity and charcoal heat sources was $3.27 \%, 3.41 \%$ and $3.43 \%$ respectively. The fibre content showed no significance $(\mathrm{p}<0.05)$ for products from the gas, electricity and charcoal heat sources respectively. The carbohydrate content of roasted plantain using gas, electricity and charcoal heat sources was $33.41 \%, 32.35 \%$ and $43.02 \%$ respectively. The increase in carbohydrate using charcoal could be as a result of low protein content (Idoko and Nwajiaku, 2013). Roasted plantains in all the heat sources showed $5 \%$ level of significance $(\mathrm{p}<0.05)$ in carbohydrate. The ash content using gas, electricity and charcoal heat sources was $7.45 \%, 8.30 \%$ and $7.00 \%$ respectively. The ash content showed $5 \%$ level of significance $(\mathrm{p}<0.05)$ for the three heat sources but there was no statistical significance between the results of the products from the gas and charcoal heat sources.

Table 2: Proximate composition of fresh and roasted plantain.

\begin{tabular}{lllll}
\hline Composition & Fresh & Gas & Electricity & Charcoal \\
\hline Moisture (\%) & $58.27^{\mathrm{a}} \pm$ & $46.26^{\mathrm{b}} \pm$ & $45.94^{\mathrm{b}} \pm$ & $39.59^{\mathrm{c}} \pm$ \\
& 0.58 & 0.40 & 0.21 & 0.53 \\
Ash (\%) & $5.89^{\mathrm{c}} \pm$ & $7.45^{\mathrm{b}} \pm$ & $8.30^{\mathrm{a}} \pm$ & $7.00^{\mathrm{b}} \pm$ \\
& 0.13 & 0.53 & 0.12 & 0.05 \\
Crude Fibre (\%) & $2.83^{\mathrm{a}} \pm$ & $3.27^{\mathrm{b}} \pm$ & $3.41^{\mathrm{b}} \pm$ & $3.43^{\mathrm{b}} \pm$ \\
& 0.07 & 28 & 0.22 & 0.17 \\
Carbohydrate & $23.80^{\mathrm{a}} \pm$ & $33.41^{\mathrm{d}} \pm$ & $32.35^{\mathrm{b}} \pm$ & $43.02^{\mathrm{c}} \pm$ \\
$(\%)$ & 0.24 & 0.38 & 0.45 & 0.14 \\
Fat (\%) & $2.16^{\mathrm{a}} \pm$ & $4.52^{\mathrm{c}} \pm$ & $4.68^{\mathrm{b}} \pm$ & $4.64^{\mathrm{c}} \pm$ \\
& 31 & 0.03 & 0.32 & 0.44 \\
Protein (\%) & $6.90^{\mathrm{a}} \pm$ & $8.11^{\mathrm{b}} \pm$ & $8.35^{\mathrm{b}} \pm$ & $5.38^{\mathrm{c}} \pm$ \\
& 16 & 0.15 & 0.14 & 0.30 \\
\hline
\end{tabular}

Data expressed as mean $\pm S D(n=3)$. Mean with different lower case letter are significantly different $(P<0.05)$

\section{Effect of Roasting Method on Micronutrients}

The values obtained for potassium, magnesium and vitamin B6 in fresh plantain samples were $240.70 \mathrm{mg} / 100 \mathrm{~g}$, $111.35 \mathrm{mg} / 100 \mathrm{~g}$ and $0.21 \mathrm{mg} / 100 \mathrm{~g}$ respectively as shown in Table 3. These values increased significantly $(\mathrm{p}<0.05)$ during roasting as a result of concentration difference, a driving potential to justify mass transfer (Ibarz and Barbosa-Canovas, 2003). Potassium, magnesium and vitamin B6 content were $309.43 \mathrm{mg} / 100 \mathrm{~g}, 119.21 \mathrm{mg} / 100 \mathrm{~g}$ and $0.26 \mathrm{mg} / 100 \mathrm{~g} ; 305.75$ $\mathrm{mg} / 100 \mathrm{~g}, 119.87 \mathrm{mg} / 100 \mathrm{~g}$ and $0.25 \mathrm{mg} / 100 \mathrm{~g}$; and 312.10 $\mathrm{mg} / 100 \mathrm{~g}, 120.39 \mathrm{mg} / 100 \mathrm{~g}$ and $0.27 \mathrm{mg} / 100 \mathrm{~g}$ for electricity, gas and charcoal heat sources respectively. The result showed that there was no significant difference in the magnesium content of roasted plantain. This could be linked to the fact that the plantains were harvested from the same farm while roasting stands to inhibit antioxidant capacity in unripe plantain (Yang and Gadi, 2008).

Table 3: Selected micronutrients in fresh and roasted plantain.

\begin{tabular}{lccc}
\hline Test Sample & $\begin{array}{l}\text { Potassium } \\
\mathbf{m g} / \mathbf{1 0 0 g}\end{array}$ & $\begin{array}{l}\text { Magnesium } \\
\mathbf{m g} / \mathbf{1 0 0 g}\end{array}$ & $\begin{array}{l}\text { Vitamin B6 } \\
\mathbf{m g} / \mathbf{1 0 0 g}\end{array}$ \\
\hline Fresh plantain & $240.70^{\mathrm{a}}$ & $111.35^{\mathrm{a}}$ & $0.21^{\mathrm{a}}$ \\
Electricity & $309.43^{\mathrm{b}}$ & $119.21^{\mathrm{b}}$ & $0.26^{\mathrm{b}}$ \\
Gas & $305.75^{\mathrm{c}}$ & $119.87^{\mathrm{b}}$ & $0.25^{\mathrm{c}}$ \\
Charcoal & $312.10^{\mathrm{d}}$ & $120.39^{\mathrm{b}}$ & $0.27^{\mathrm{d}}$ \\
\hline Mean with different lower case letter & are significantly different $(P<0.05), n=3$
\end{tabular}

\section{Effect of Roasting Method on Sensory Evaluation}

Sensory result showed that average score of male and female respondents for sample 1, 2 and 3 were 3.84 and 3.96; 3.66 and 3.71 ; and 4.52 and 4.63 respectively as shown in Figure. 4. The assessment by both groups of respondents followed the same trend with preference for roasted plantain using charcoal heat source. Gradual roasting influenced by prolongs residence time exhibited by charcoal heat source produced sweet smelling flavour with wide acceptability. In other word, it enhanced moisture removal from the interior (Sanni et al., 2016). Thus, the characteristic eating quality and suitability of the food was determined.

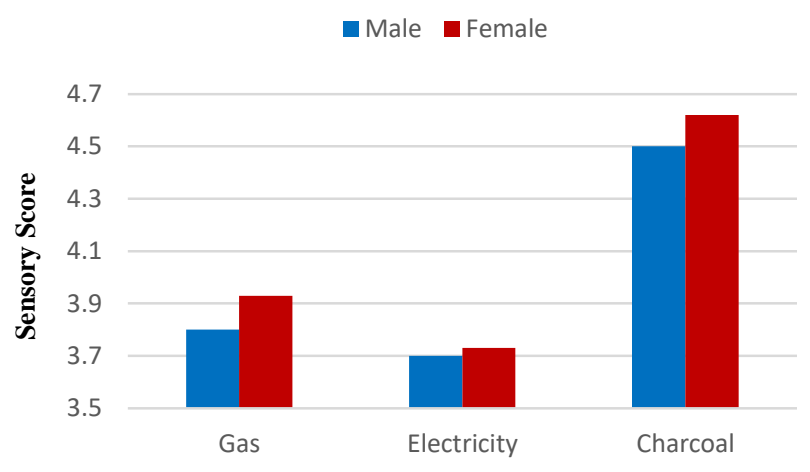

Figure 4: Effect of roasting method on sensory attributes of plantain. 


\section{CONCLUSION}

A manually operated multi-heat source plantain roaster was designed, fabricated and evaluated. The following conclusions were drawn from the study:

1. There was a significant difference in the proximate, mineral and Vitamin B6 levels of fresh unripe and roasted plantains using different heat sources.

2. Mean separation using Duncan multiple range test also showed significant difference in potassium and vitamin B6 of roasted plantain.

3. Consumer perception of the roasted plantain indicated that charcoal was most preferred and acceptable to the panelists.

4. These results suggest that the multi-heat source plantain roaster is affordable and could be easily adopted for the purpose of upgrading the rural technology of plantain roasting, and eliminating the associated drudgery and likely contamination of such products.

\section{REFERENCES}

Adegboyega, O.K. (2006). Chemical Ccomposition of Unripe (green) and Ripe Plantain (Musa paradisiaca). The Pacific Journal of Science and Technology, 16(1): 51-53.

Adewumi, B.A. (2007). Effect of some Crop Parameters on the Performance Characteristics of a Manually Operated Plantain Chipping Machine. Botswana Journal of Engineering, 16(2): $23-28$.

Akomolafe, O.M. and Aborisade, A.T. (2007). Effects of Stimulated Storage Condition on the Quality of Plantain (Musa paradisiaca) Fruits. International Journal of Agricultural Research, 2(12): 1037 - 1042.

AOAC (2000). Official Methods of Analysis $17^{\text {th }} \mathrm{Ed}$. Association of Official Analytical Chemist, Washington D.C.

AOAC (2005). Official Methods of Analysis $18^{\text {th }}$ Ed. Association of Official Analytical Chemist, Washington, D.C.

Awopetu, 0.O. and Aderibigbe, A.F. (2017). Development of a Manually Operated Multi-Purpose Roasting Machine. British Journal of Applied Science \& Technology, 20(1): 1-7.

Ayodele, O.H. and Erema, V.G. (2011). Glycemic Index of Processed Unripe Plantain Meals, African Journal of Food Science. 4: 514-521.

Castello, B. (2006). Complete Guide to Bananas. Retrieved on February 9, 2007 from http://www.banana.com.

Eleazu, C.O.; P.N. Okafor and A.I. Ikpeama. (2010). Total Antioxidant Capacity, Nutritional Composition and Inhibitory Activity of Unripe Plantain (Musa paradisiacae) on Oxidative Stress in Alloxan Induced Diabetic Rabbits. Pakistan Journal of Nutrition, 9 (11): 1052-1057.

Ezekiel, O.O.; R. Akinoso and D.J. Olaoye. (2012). Design, Fabrication and Evaluation of a Plantain Roaster. Nigerian Food Journal, 30(1): 131 - 138.
FAO, (2010). Maize, Roots, Plantains and Bananas in Human Nutrition. Retrieved from http://www.fao/docrep. html on 15th January, 2010.

Fellows, P.J. (2000). Food Processing Technology, Principles and Practice. $2^{\text {nd }}$ Edition. Wood Head Publishing Ltd. England, 234-280.

Ibarz, A. and Barbosa-Canovas, G.V. (2003). Unit Operation in Food Engineering, CRC Press: New York Washington, D.C.

Idoko, J.O. and Nwajiaku, I. (2013). Performance of Ripe and Unripe Plantain-Wheat Flour Blend in Biscuit Production. International Journal of Biological Food Veterinary and Agricultural Engineering, 7(12): 848-851.

Ilori, T.A.; A.O. Raji; A.O. Adejumo and O. Kilanko. (2014). Development and Performance Evaluation of a Maize Roaster. International Journal of Science, Technology and Society, 2(5): 161-164.

INIBAP, (2003). Annual Report, International Network for Improvement of Banana and Plantain: Biotechnology Applications for Banana and Plantain Improvement, 12-26.

Izunfuo, W. and Omuaru, V.O.T. (2006). Effect of Ripening on the Chemical Composition of Plant Peels and Pulps (Musaparadisiaca). Journal of Science Food and Agriculture, 45(5): 333-336.

Jimoh, M.O. and Ogunmoyela, O.A.B. (2017). Influence of Thermal Properties on Fat Uptake in Deep-Fried Plantain Chips, Journal of Industrial Research and Technology, 6(1): 63-74.

Kusano, S.; H. Abe and H. Tamura. (2001). Isolation of Antidiabetic Components from White Skinned-Sweet Potato (Ipomoeabatas L.). Bioscience, Biotechnology and Biochemistry, 65(1): 109-114.

Kusano, S.; S. Tamasu.and S. Nakatsugawa. (2005). Effects of the White-Skinned Sweet Potato (Ipomoeabatatas L.) on the Expression of Adipocytokine in Adipose Tissue of Genetic Type, Diabetic Mice, Food Science and Technology Research, 11(4): 369-372.

Makanjuola. O.M.; A.B. Ajayi; K. Mathew and J.O. Makanjuola. (2013). The Proximate Composition and Mineral Contents of Three Plantain Cultivars Harvested at Matured Green Level. International Journal of Innovations in Bio-Sciences, 3(2): 23-26.

Marisa, M.W. (2006). Ascorbic Acid, Vitamin A, and Mineral Composition of Banana (Musa sp.) and Papaya (Carica papaya) Cultivars Grown in Hawaii. Journal of Food Composition and Analysis, 19: 434-445.

Ogabi, O.N. (2018). Development and Performance Evaluation of a Multi-Heat Source Plantain Roaster. Unpublished M. Tech. Thesis, Department of Chemical and Food Sciences, Bells University of Technology, Ota, Nigeria.

Ogunmoyela, O.A.B.; M.O. Jimoh and O.N. Ogabi. (2016). Development and Evaluation of a Multi-Heat Source Deep Fat Fryer. African Journal of Food Science and Technology, 7(3): $\quad$ 51-59.

Oke, P.K. (2013). Development of a Multi-Purpose Roasting Machine. Pacific Journal of Science and Technology, 14(2): 48-53. 
Oke, P.K. and Ogundare, A.A. (2012). Development of Mechanized Plantain Slicing Machine. Journal of Emerging and Trend in Engineering and Applied Science, 3(1): 56 -60.

Sanni, L.A.; O.O. Odukogbe and M.O. Faborode. (2016). Some Quality Characteristics of Gari as Influenced by Roasting Methods, Agric Eng Int: CIGR Journal, 18(2): 388394.

Toledo, R.T. (2000). Fundamental of Food Processing Engineering 2nd Edition. CBS Publishers \& Distribution, New Delhi, Indian.
World Health Organization, (2004). The World Health Report - Changing History, Geneva.

Yang, J. and Gadi, R.L. (2008). Effects of Steaming and Dehydration on Anthocyanins, Antioxidant Activity, Total Phenols and Colour Characteristics of Purple-Fleshed Sweet Potatoes (Ipomoea batatas). American Journal of Food Technology, 3(4): 224-234. 